\title{
スギ林における間伐区と無間伐区の 積雪深の比較
}

\author{
野口 正二 1)，金子 智紀 2)，和田 覚 2)，石川具視 2) \\ 1）(独）森林総合研究所東北支所 \\ （干020-0123 盛岡市下㴻川字鍋屋敷92-25） \\ 2) 秋田県農林水産技術センター森林技術センター \\ （テ019-2611 秋田市河辺戸島字井戸尻台47-2）
}

\begin{abstract}
秋田県長坂試験地のスギ林における間伐区（間伐斜面・作業路）と無間伐区および気象露場において，2008-2009 年冬期に積雪深を比較検討した，積雪深は，鋼尺を用いて測定するとともに，高さ $0,25,50,75 \mathrm{~cm}$ に設置した温 度センサーによる推定も試みた。堆積期において積雪深は，気象露場 $>$ 作業路 $>$ 間伐斜面 $>$ 無間伐斜面の順で深 かった．融雪期において積雪深の低下は，気象露場 >間伐斜面または作業路 >無間伐斜面の順で早かった．積雪深 は，樹冠開空度の大きさによって異なり，降雪遮断量と放射収支量の影響を受けていると考えられたままた，作業 路において融雪出水時の地中水の影響と思われる積雪深の著しい低下が認められた. 感温式積雪計は, 多支柱式を 使用することによって林内の積雪深の測定に有効と考えられた，さらに，地表に設置した温度センサーは，積雪下 で生じる地中流の発生を把握するのにも有効と考えられた.
\end{abstract}

キーワード：融雪水, 間伐, 温度センサー, 作業路, 樹冠開空度

\section{I. はじめに}

積雪地域において，森林流域にもたらされた雪は 冬期に固体物として地上に一時蓄積され，春先に融 雪水となり重要な水資源として利用されている。森 林施業が水流出に及ぼす影響について, 皆伐が融雪 期前半の雪代水による流出量を増加させ，後半の流 出量を減少させること（中野·菊谷，1956）, 融雪 流出期間を短縮させるが流出率はほとんど変化させ ないこと（志水，1990）が報告されている。また, 志水・吉野（1996）は流域の約50％の帯状伐採に よって, 融雪流出期間が長くなり, 融雪期の流出率 の増加を報告している。しかし，これらの報告では， 流域内部の積雪の変化について言及していない.

電源のない山地での積雪深の測定は, 古くはピン ホールカメラの原理を利用した自記積雪深計が考案 され (大沼・小島, 1950), 集水区域の積雪の標高 分布の時間変化が観測された（大沼ら，1954）。 そ の後, 光ファイバー式積雪深計や光センサー式積雪 深が商品化され使用されている（播磨屋，1991）。 しかし, これらの観測機器は流域内に多点に設置し
て測定するほど簡易・安価ではない。流域内の積雪 深を多点で計測するに当たって, 安価で設置が簡易 な方法として最大積雪深計が考案され（高橋喜平, 1968), 広く利用されているものの, この方法は一 シーズンの積雪深の最大值の情報が得られるのみ で，積雪深の変化など時間の情報を得ることができ ない。一方，広域な流域を対象とした積雪深の測定 には空中写真が活用され（高崎ら，1964；杉山， 1970)，近年はレーザプロファイラーによる計測が 実施されている（岡本ら，2004; Tsuboyama et al., 2008)。しかし, 連続的なデー夕を得るためには費 用が高く簡便でないという久点がある. 以上の事項 を考慮して, 比較的安価で設置が簡易な方法として 温度センサーを使用した積雪深計（：感温式積雪深 計）が発案されている（大原，2008）.

東北地方では平成18年に福島県（森林環境税）と 岩手県（いわての森林づくり県民税）で, 平成19年 に山形県（やまがた緑環境税）で，平成20年に秋田 県（水と緑の森林づくり税）で環境税が導入されて きた。環境税の導入とともに, 県では間伐事業を進 
めている。そのような背景から，森林伐採に伴う水 流出特性の変化について関心が高まっている.

秋田県は森林の水土保全機能に関するモニタリ ング事業の一環として大館市長坂県営林に試験地 （：長坂試験地）を設定し，2002年から3つの流域 を対象として水文観測を開始した。その後，2007年 2月～3月に $2 つ の$ 流域を対象として立木本数 $50 \%$ の 割合で間伐を実施し，間伐による水流出特性の変化 を検証中である。本研究では, 樹冠開空度と積雪調 査による積雪深の測定結果とともに, 温度センサー による感温式積雪深計を用いて，スギ林の間伐区と 無間伐区の積雪深を比較検討することを目的とする.

\section{II . 研究方法}

\section{1. 試験地概要}

本研究は, 秋田県大館市長坂地内の長坂試験地 (北緯40度16分, 東経140度24分）を対象とした。試 験地内の上の沢流域で，2007年2月～3月に作業路の 作設を伴う立木本数で約 $50 \%$ の間伐を実施した。 作業路は流域の中腹を等高線に沿って周回する様に バックホウ（コベルコ，0.25 t）で作設された（総 延長: $780 \mathrm{~m}$; 平均切土高: $83 \mathrm{~cm}$; 平均幅員 : 265 $\mathrm{cm}$; 平均縦断勾配 : $\left.7.9^{\circ}\right)$. 間伐された立木につい て, 小径木は切り捨てされ, 材積量で約 $80 \mathrm{~m}^{3}$ の立 木がグラップル (コマツ, $0.25 \mathrm{t}$; KATO, $0.25 \mathrm{t}$ ) とキャリア $(3.5 \mathrm{t})$ を使用して流域外へ搬出された. 作業路の地表面について, 重機による圧密を受けて 䡴の部分 (平均硬度：263 $\mathrm{kPa}$ ) は中央部 (平均硬 度：128 kPa）や盛土部（平均硬度：128 kPa）と比 較して高い土壤硬度を示した。標高, 斜面方位, 傾 斜が類似する調査区を上の沢流域内の斜面（標高： 118-124 m, 斜面方位：南, 傾斜 : $22^{\circ}$ ) と隣接す 万無間伐斜面（標高：122-133 m, 斜面方位：南, 傾斜：20 ）に選定した。流域地質は第三紀凝灰岩 （グリーンタフ）で, 土壤は淡色性黒ボク土壤及び 適潤性褐色森林土壤である。植生はスギを主とする 人工林で, 山腹上部に落葉広葉樹のコナラやミズ ナラなどが混在する（金子ら，2010）。気象露場 (標高：100 m) は, 上の沢流域から約 $200 \mathrm{~m}$ の距離 に位置する。

試験地から南南西に約7 km離れた鷹巣のアメダス (北緯40度13.6分, 東経140度22.3分, 標高：29 m) によれば，年平均降水量は1,660 mm（1979～2000年） であり，年間を通じて，7月 $(203.5 \mathrm{~mm})$ と8月
$(190 \mathrm{~mm})$ に降水量が多い. 年平均気温の平年值は $10.0{ }^{\circ} \mathrm{C}$ で, 1 月に最低值 $\left(-1.9{ }^{\circ} \mathrm{C}\right), 8$ 月に最高值 $\left(23.5{ }^{\circ} \mathrm{C}\right)$ を示す。また，年最大積雪深は， $27 \mathrm{~cm} \sim$ $129 \mathrm{~cm}$ (平均值：74 cm；1991～2008年）である (気象庁, 2009).

\section{2. 測定と解析}

間伐区の斜面と作業路（中央部）および無間伐区 の斜面において，代表的な 1 地点にそれぞれ地表 $(0$ $\mathrm{cm})$, 高さ $25 \mathrm{~cm}, 50 \mathrm{~cm}$ および $75 \mathrm{~cm}$ の高度に温度 センサーを設置した。温度センサーによる積雪の計 測は, 積雪中の温度変化が外気温より遅れることを 利用し, 外気温と所定の地上高の温度を比較するこ とにより，その高さにおける積雪の有無を判断する ものである。このような原理に基づく積雪深計を以 下では感温式と呼ぶ. 温度センサーはボタン電池型 の超小型温度データロガー (サーモクロン Gタイプ, KNラボラトリーズ）を使用した。このセンサーは 1 回の計測記憶数が最大で 2,048 回であることから, 1 冬期測定可能にするために測定インターバルを 2 時 間に設定した。

測定期間中に間伐斜面 (4地点), 作業路（3地点）, 無間伐斜面（5地点）および気象露場（1地点）にお いて，鋼尺を用いて積雪深の測定を7回（2009年1月 8 日，1月22日，2月5日，2月18日，3月3日，3月17日， 3月27日）実施した。

気象露場において測定した気温は積雪深の測定の ための温度センターに合わせて，2時間インターバ ル值を使用した (S-THB, Onset社)。融雪水量は, $1 \mathrm{~m} \times 1 \mathrm{~m}$ の枠を設置して100 ccの転倒マス流量計を 使用して測定した。降水量は転倒升型の溢水式雨雪 量計 (B-071, 横河電子機器製) を地上 $3 \mathrm{~m}$ の高さに 設置して測定した。また，近傍の湿地で地表と高さ $25 \mathrm{~cm}$ の温度 (サーモクロン $\mathrm{G}$ タイプ, KNラボラト リーズ）を測定した。上の沢の流出量の観測は, $60^{\circ} \mathrm{V}$ ノッチ式量水堰堤に扔いて, 圧力式水位計を 用いて行った。

樹冠の開空度を測定するために, 魚眼レンズ （FC-E8）を装着したデジタルカメラ（Nikon Cool Pix4500）を用いて, 間伐斜面, 作業路抢よび無間 伐斜面を対象として，それぞれ6地点で2009年3月3 日に全天写真を撮影した。得られた写真から解析ソ フト (Hemiview; Delta-T Devices Ltd, UK) を用いて 開空度を求めた。なお，写真には半球全体が撮影さ れるが，斜面で撮影した写真には地表面が含まれて 
いる。その地表部を除去するために撮影された領域 を絞り, 天頂角 $20^{\circ}$ の範囲の開空度を算出し解析に 用いた。

統計解析には，SPSS17.0（SPSS，Japan）を使用し た３地点間に扔ける多重比較検定は，ボンフェロー 二の不等式による修正を利用し，ウィルコクスンの 順位和検定を行った。

\section{III. 結果}

\section{1. 樹冠開空度}

写真一 1 に無間伐斜面，間伐斜面および作業路で 撮影した全天空写真を示す。各地点における樹冠開 空度の最小值，最大值および平均值は，無間伐斜面 で10.5\%, $27.4 \%$ および $16.3 \%$, 間伐斜面で $30.7 \%$, $43.3 \%$ および35.5\%，作業路で56.6％，75.8％およ び69.7\%であった．樹冠開空度の大きさは，無間伐 斜面＜間伐斜面＜作業路の順番を示し，各地点間の 值について統計的に有意差があった $(\mathrm{p}<0.016)$.

\section{2. 積雪深の変化}

7回の積雪調査による積雪深（各地点での平均値） とアメダス・鷹巣での積雪深の測定結果を図ー1に 示す。最大值は4回目（2月18日）もしくは5回目（3 月3日）の計測時において測定され，1回から5回目 までの計測時において, 気象露場 $>$ 作業路 $>$ 間伐斜 面＞無間斜面の順で積雪深が変化した。 6回目（3月 17日）と7回目（3月27日）の計測時において, 間伐 斜面と無間伐斜面における積雪深の順序が入れ替わ り, 気象露場 $>$ 作業路 $>$ 無間伐斜面 $>$ 間伐斜面の順 となった。鷹巣での積雪深は, 試験地での観測值よ り低い值を示し変化した。2009年2月3日に最大值56 $\mathrm{cm}$ を記録し，2009年3月16日に試験地よりも早く消 雪した。また，2009年2月18日に試験地を踏査したと
ころ，作業路の山側で積雪の深い溝が生じ，一部分 で地表面が露出し表面流も確認された（写真一2）.

\section{3. 感温式積雪計による積雪の状況の推定}

図一2に気象露場の気温と作業路に扔ける温度の 測定結果を示す。測定を開始した2008年12月25日に はすでに地表に積雪があったため, 地表面 $(0 \mathrm{~cm})$ の温度は $0{ }^{\circ} \mathrm{C}$ 付近を示した. その後, 根雪になった と考えられ，消雪したと判断された2009年4月4日ま で $0{ }^{\circ} \mathrm{C}$ 付近の一定の温度を示した. 設置したセン サーの高さが高くなるに従い, 温度が $0{ }^{\circ} \mathrm{C}$ 付近で一 定になる日が遅く, 雪面上に出現したと判断される 日が早かった。高さ別の温度変化の傾向は, 間伐斜 面および無間伐斜面でも同様であった（表一 1 )。温 度センサーによる積雪の形成日と消失日の推定結果 を見ると, 形成日は気象露場近傍, 作業路, 間伐斜 面，無間伐斜面の順で早かった。また，間伐斜面と 作業路では， $50 \mathrm{~cm}$ 積雪深が認められるが無間伐 斜面では認められなかった。消失日は無間伐斜面が 一番早く, 次いで作業路または気象露場近傍, 間伐 斜面の順で早かった（表一1）.

\section{IV. 考察}

積雪の変化は堆積期と融雪期に区分できる (大畑, 1995)。鷹巣での積雪深の変化は, 堆積と融雪を繰 り返す暖冬年の傾向を示しているが，ここでは7回 の積雪調查結果から3月3日を境に堆積期と融雪期に 区分して考察する。また，温度センサーによる積雪 深の計測について考察する。

\section{1. 堆積期}

後藤ら（1993）はヒノキ林における積雪深と樹冠 開空度の関係を検討し，堆積期の積雪深は，樹冠開
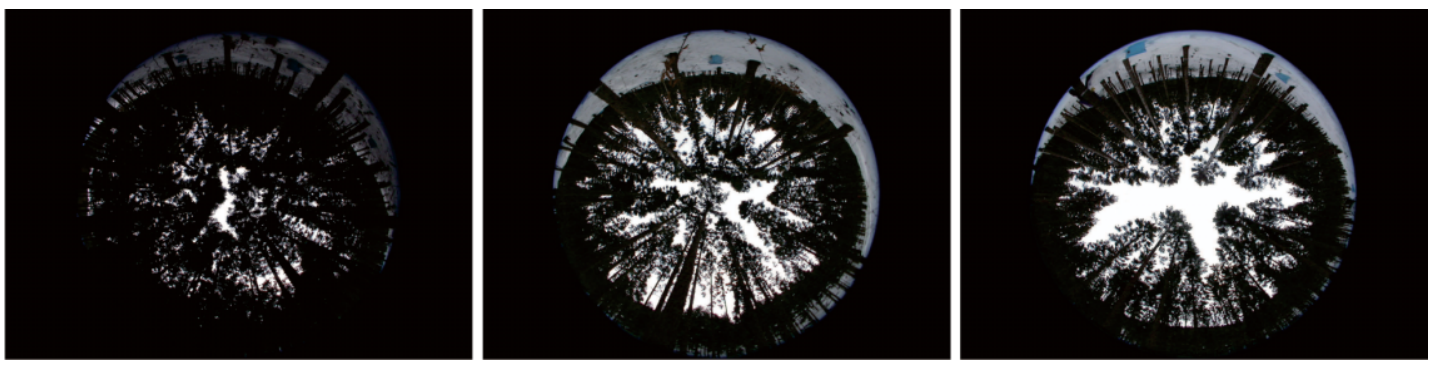

写真 -1 無間伐斜面（左）間伐斜面（中央）および作業路（右）に扔ける全天空写真

Photo.1 Hemisphere photographs at unthinned slope (left), thinned slope (center) and skid trail (right). 


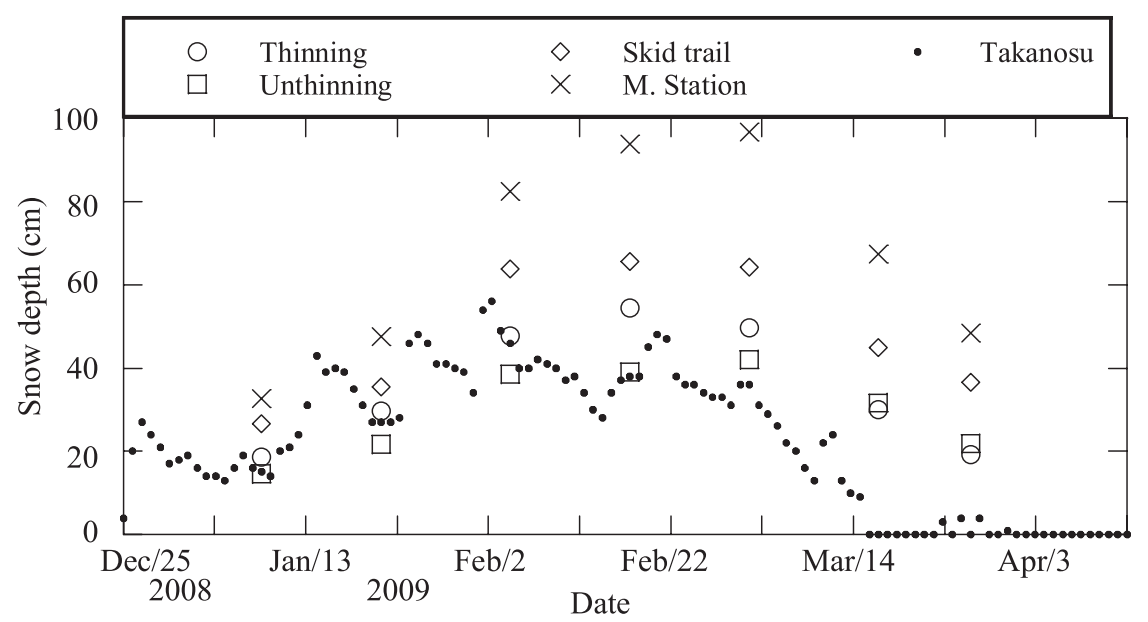

図-1 積雪調査による積雪深の測定結果 (間伐区, 無間伐区, 作業路, 気象露場)とアメダス・鷹巣での積雪深の変化

Fig. 1 Snow depth based on surveying snow at the thinned slope, the skid trail, the unthinned slope, and the meteorological station and variation of daily snow depth at the Takanosu of AMeDAS.

空度の増加 $(10 \sim 50 \%)$ に伴い増加する傾向を示 した。また，野口・西園（2010）は，積雪期の落葉 広葉樹林と常緑針葉樹林の樹冠通過降水量を比較 し, 樹冠開度が大きな落葉広葉樹林で, 常緑針葉樹 林より樹冠通過降水量が20４0％多いことを示し た。本研究での積雪深の測定結果は, 樹冠開空度の 大きさと同様に気象露場 $>$ 作業路 $>$ 間伐斜面 $>$ 無間 伐斜面の順で，既往の結果と同様であった。

\section{2. 融雪期}

融雪期の積雪深の減少に着目すると，3月3日～3 月17日に拈いて, 気象露場 $(29 \mathrm{~cm})>$ 間伐斜面 $(20 \mathrm{~cm})$, 作業路 $(19 \mathrm{~cm})>$ 無間伐斜面 $(11 \mathrm{~cm})$ の順で, 3月17日〜3月27日に扮いて, 気象露場（19 $\mathrm{cm})>$ 間伐斜面 $(11 \mathrm{~cm})$, 無間伐斜面 $(10 \mathrm{~cm})$, 作 業路 $(8 \mathrm{~cm})$ の順であった。林内の融雪量は放射収 支量の大きさに依存し（橋本ら，1992）, 中林ら （1996）は全天空写真から樹冠の開空度が80％まで 増加するほど放射収支量が増加することを示した。 また, 北村ら（1970）は, スギ幼齢林において急傾 斜な場所, 小尾根および受光係数の大きい場所で積 雪深は速く減少し, 樹高 $6 \mathrm{~m}$ 以上の立木本数の多い 場所で積雪深の減少が遅いことを指摘している。間 伐区と無間伐区は斜面方位，傾斜及び標高は同様で あることから，樹冠開空度の違いによる放射収支量 の違いが積雪深の変化に影響を及ぼしていると考え られた。

写真一2のような現象の原因を考察するために,
図一3に2009年2月13日〜2月18日の上の沢の流域流 出量, 降水量, 融雪水量, 気温㧍よび気象露場近傍 の湿地での地表と高さ $25 \mathrm{~cm}$ の温度の測定結果を示 す。試験地を踏査する直前の2009年2月13日20：00か ら14日にかけて降水イベント（総降水量： $67 \mathrm{~mm}$, 最大降水強度：10.0 $\mathrm{mmh}^{-1}$ ) が生じた. 最大降水強

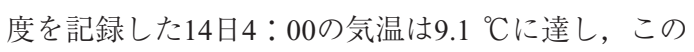
時の降水イベントは降雨と判断される. 気象露場近 傍の湿地に扔いて, 高さ $25 \mathrm{~cm}$ の温度は変化してい ないが, 融雪水量がピークに達した14日4：00以降

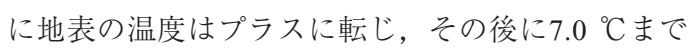
上昇した。また, 上の沢の流出量は, 融雪水量に対 して4時間遅れてピークに達し緩やかに低減した。 地表の温度は, 上部が積雪で覆われていること, 積 雪内を流下した融雪水や雨水の温度は $0{ }^{\circ} \mathrm{C}$ で融雪水 量の減少後も引き続き高い温度を示していること, 融雪出水が融雪水量の減少後も認められることか ら，地中水を起源とする水温を計測していると考え られる。作業路の切土断面では, 難透層を制限とし たところから地中流の流出が生じ, 作業路面を流下 し侵食することが知られている（例えば，Ziegler, 2006). 本調査地に打いても, 作業路の切土断面か ら流出した地中水が作業路面上を流下することが確 認されている $($ 写真一2)。作業路の積雪深が著しく 低下していたことや消失していたことは (写真一2), 作業路の切土断面からの地中水の流出の影響と考え られた。 


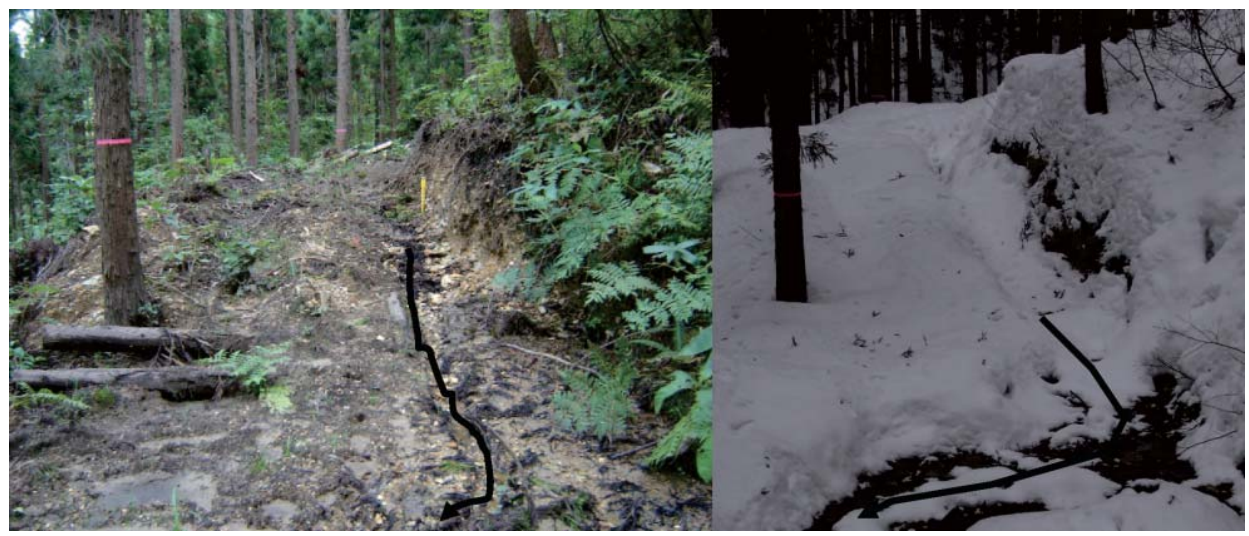

写真一2 無積雪期と積雪期における上の沢流域における作業路の様子. 矢印は表面流の方向を示す

Photo. 2 The skid trail in the upper catchment during the no-snow and snow cover periods. Arrows indicate the direction of surface water flow.
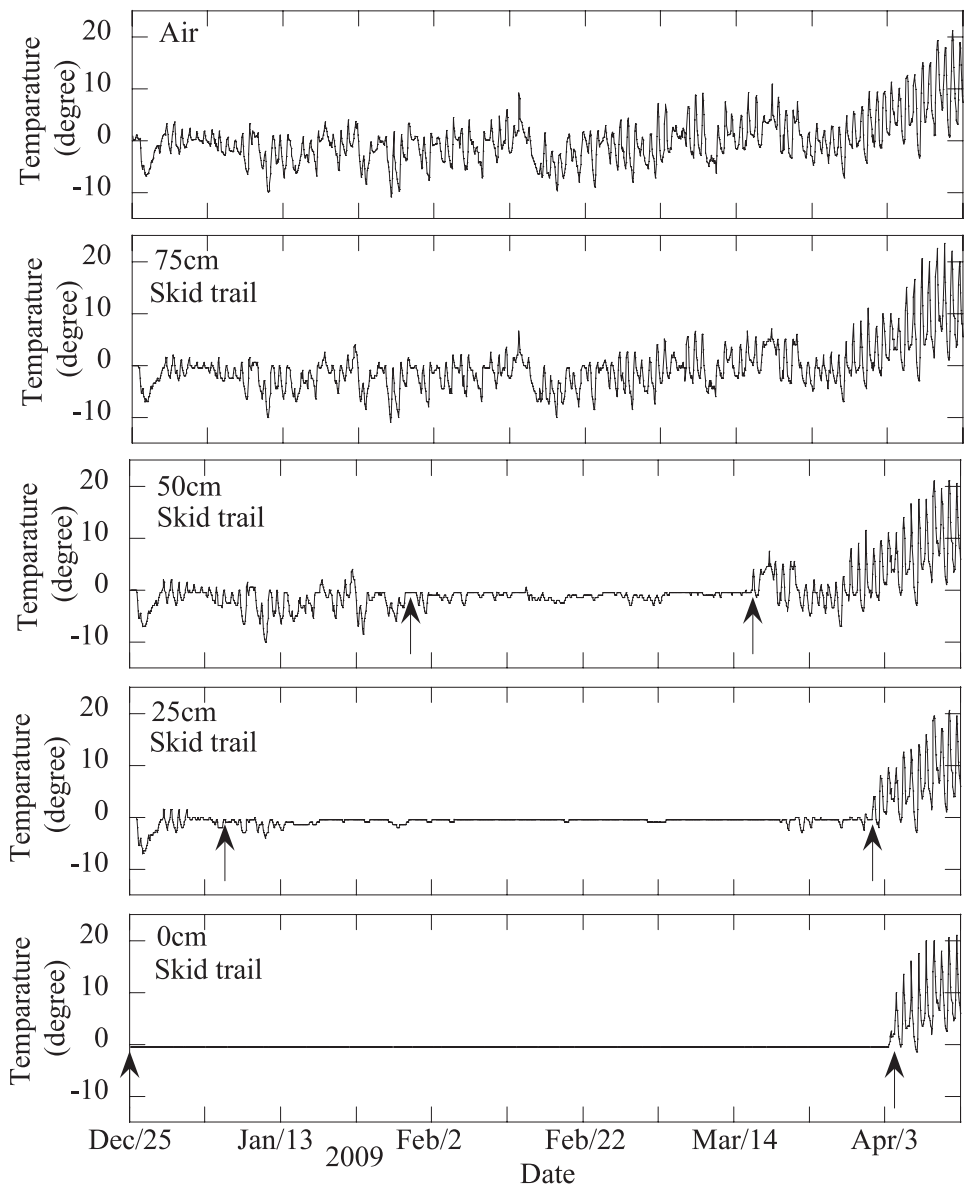

眓-2 気象露場での気温および作業路（表層, 高さ $25 \mathrm{~cm}, 50 \mathrm{~cm}, 75 \mathrm{~cm}$ ) における温度測定結果 矢印は推定された積雪の形成日と消雪日を示す

Fig. 2 Air temperature at the meteorological station and temperatures at $0 \mathrm{~cm} ; 25 \mathrm{~cm}, 50 \mathrm{~cm}, 75 \mathrm{~cm}$ height in the skid trail. Arrows indicate starting and ending days with snow cover. 


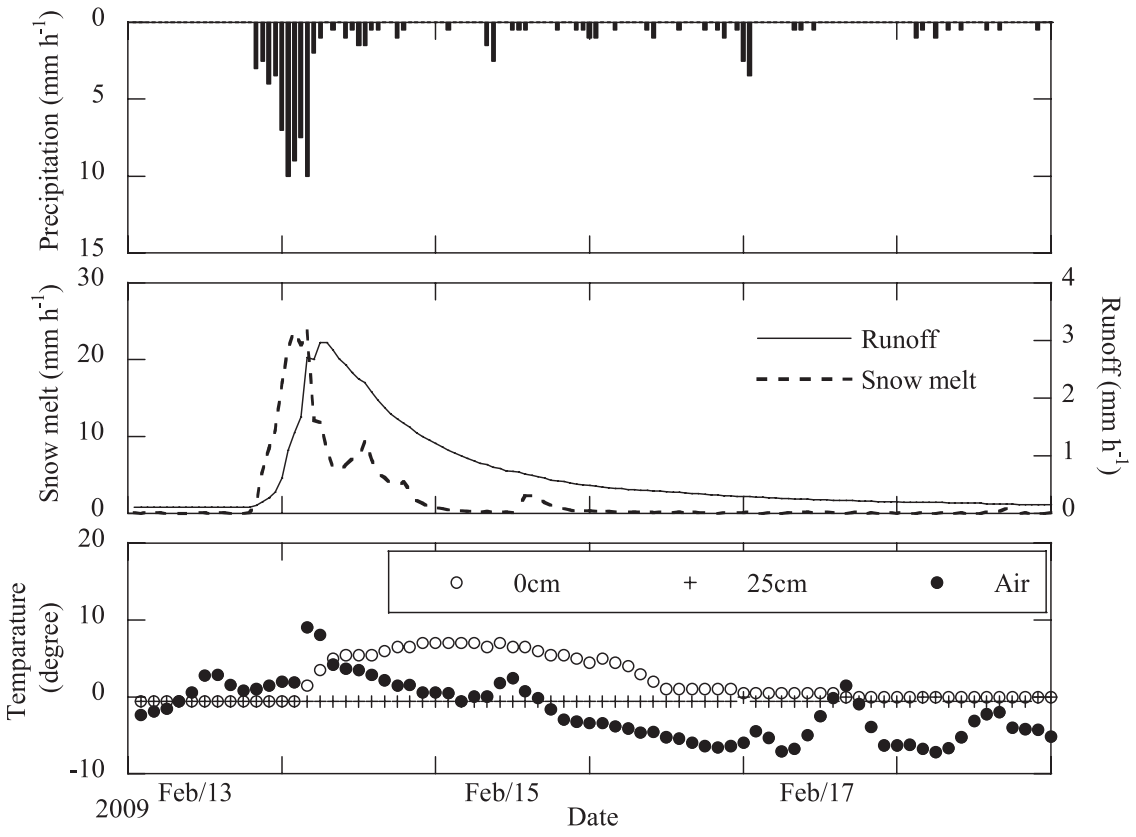

図-3 上の沢の流出量, 気象露場における降水量, 融雪水量, 気温, および気象露場近傍の湿地での地表と高さ $25 \mathrm{~cm}$ の温度

Fig. 3 Runoff at the upper catchment, precipitation, snow melt, and air temperature at the meteorological station, and temperature at $0 \mathrm{~cm}$ and $20 \mathrm{~cm}$ in wet land near the meteorological station.

表ー1 温度センサーによる積雪の形成日と消雪日の推 定結果

Table 1 Result for starting and ending days with snow cover estimated by the temperature sensor.

\begin{tabular}{c|c|c|c}
\hline 場所 & 地表からの高さ & 積雪の形成日 & 積雪の消雪日 \\
\hline \multirow{4}{*}{ 無間伐斜面 } & $0 \mathrm{~cm}$ & $2008 / 12 / 25$ & $2009 / 04 / 02$ \\
& $25 \mathrm{~cm}$ & $2009 / 01 / 30$ & $2009 / 03 / 19$ \\
& $50 \mathrm{~cm}$ & - & - \\
& $75 \mathrm{~cm}$ & - & - \\
\hline & $0 \mathrm{~cm}$ & $2008 / 12 / 25$ & $2009 / 04 / 07$ \\
間伐斜面 & $25 \mathrm{~cm}$ & $2009 / 01 / 19$ & $2009 / 04 / 01$ \\
& $50 \mathrm{~cm}$ & $2009 / 02 / 05$ & $2009 / 03 / 08$ \\
& $75 \mathrm{~cm}$ & - & - \\
\hline & $0 \mathrm{~cm}$ & $2008 / 12 / 25$ & $2009 / 04 / 04$ \\
作業路 & $25 \mathrm{~cm}$ & $2009 / 01 / 06$ & $2009 / 04 / 02$ \\
& $50 \mathrm{~cm}$ & $2009 / 02 / 01$ & $2009 / 03 / 17$ \\
& $75 \mathrm{~cm}$ & - & - \\
\hline 気象露場近傍 & $0 \mathrm{~cm}$ & $2008 / 12 / 25$ & $2009 / 04 / 05$ \\
の湿地 & $25 \mathrm{~cm}$ & $2009 / 01 / 01$ & $2009 / 03 / 21$ \\
\hline
\end{tabular}

\section{3. 感温式積雪計による林内の積雪深の測定}

温度センサーを支柱に取り付け計測する際, 1本 の支柱に所定の高度に区分した温度センサーを装着 した垂直配置の1支柱式と, 支柱の最上端のみに温
度計を取り付けたものを高さ別に階段状に配置する 多支柱式が提案されている（大原，2008）。前者の 場合は融雪時に㧈いて，樹木の輻射熱によって樹木 周辺が早く融雪するように支柱周辺が早く融雪する ことが考えられ, 最長の75 $\mathrm{cm}$ の支柱で顕著に確認 された。また, 後者の場合は, 測定高度が多数にな るほど，支柱を設置するための場所が必要となる。 林内の積雪深について, 木の根元は積雪深が浅いこ と（吉田，1962）や林縁は降雪の滴下の影響がある ことが指摘されている (Schmidt and Pomeroy, 1990). 林内で多くの高さで積雪深を測定する場合, 樹木位 置や樹冠の不均質性による積雪深のばらつきの影響 を受けないように設置場所を考慮する必要がある。

今回は林縁や樹木の近傍を避けて, 支柱の輻射熱 の影響を最小限にするために多支柱式で積雪深を測 定した。その結果, 堆積期に扔いてマニュアルでの 積雪深測定結果と同様に作業路，間伐斜面，無間伐 斜面の順で早く積雪していた（表一1）。融雪期にお いて，積雪深はマニュアルでの計測と異なる傾向が あったが, 積雪深の低下について着目すると, 同様 に作業路，間伐斜面，無間伐斜面の順に早く低下し ていると推定された $($ 表一 1$)$. さらに, 地表 $(0 \mathrm{~cm})$ 
に設置した温度センサーによって消雪のタイミング を明瞭に判断することができた（図一2）。このこと から, 実際に測定が困難な山地森林内において, 感 温式積雪計は, 測定高度の数を限定し多支柱式を適 用することによって有効だと考えられた。ただし， 本研究のように 2 時間インターバルの計測では, 温 度計測位置が積雪中にあるか外気に晒されているか 判断することが困難な場合があった．測定インター バルをさらに短くした方がより良いと考えられた。

\section{V.おわりに}

堆積期に扔いて積雪深は, 気象露場 $>$ 作業路 $>$ 間 伐斜面>無間伐斜面の順で深かった。融雪期におい て積雪深の低下は, 気象露場>間伐斜面または作業 路>無間伐斜面の順で早かった。感温式積雪計は, マニュアルでの計測と同様な結果を示し, 山地森林 内で積雪時期を把握するのに有効だと考えられた。 また，地上に設置した温度センサーは，消雪のタイ ミングに加え, 積雪下で生じる地中流の発生を把握 するのに効果的と考えられた。間伐によって林内へ の放射収支量の増加により, 積雪深が変化し, 融雪 時の水流出特性に影響を及ぼすことが考えられる. 今後，間伐によって流域内の光環境がどのように変 化したか明らかにするとともに，森林流域内の斜面 方位や林況が異なる地点で積雪深の変化を明らかに し, 積雪期において積雪深の変化が水流出特性に及 ぼす影響を明らかにすることが課題である。

\section{謝辞}

作業路に関する情報は，梅田修史氏，鈴木秀典氏， 山口智氏らによる測量結果を使用させて頂いた。こ こに記して感謝の意を表します。本研究は新たな農 林水産政策を推進する実用技術開発事業の補助を受 けて実施しました。

\section{参考文献}

後藤義明・大丸裕武・森澤 猛 (1993): 開空度の違いによる森林 の積雪深変化, 雪水, 55, pp.197-205.

橋本 哲・太田岳史・石橋秀弘 (1992) 落葉樹林が表層融雪量に 与える影響に関する熱収支的検討, 雪水, $52, \mathrm{pp} .131-143$.

播磨屋敏生 (1991)：1. 降雪・積雪の深さの調査法, 雪水調査法 (日本雪水学会北海道支部編), 北海道大学図書刊行会, pp.3-4. 金子智紀・武田響一・野口正二·大原偉樹 - 藤枝基久 (2010): 積 雪地帯の近接したスギ人工林3小流域における流出特性の比較, 日本森林学会誌, 92 : (印刷中).

気象庁: “過去の気象データの検索”, http://www.data.jma.go.jp/obd/stats/etrn/index.php. (参照: 2009/08/31).

北村昌美・須藤昭二・石橋秀弘 (1970) : スギ幼齢林における積雪 深と微細地形との関係について(第1報), 雪水, 32, pp.4-9.

中林宏典・石川信敬・児玉裕二 (1996) : 融雪期における林内放射 収支量の開空率依存性, 雪水, 58, pp.229-237.

中野秀章·菊谷昭雄 (1956): 森林伐採と融雪. 日本林学会誌, 38, pp.314-316.

野口正二・西園朋広 (2010) : 積雪期の常緑針葉樹林と落葉広葉 樹林における樹冠通過降水量の比較, 日本森林学会誌, 92, pp.29-34.

大畑哲夫 (1995): 積雪と積雪現象, 降雪現象と積雪現象 (前野紀 一・福田正己編), 古今書院, pp.153-182.

大原偉樹 (2008): 感温式積雪深計およびその計測方法. 公開特 許公報（A） P2008-20260A.

大沼匡之・浅田暢彦・大場多藏 (1954)：Snow-Recorderについ て, 雪水, 16, pp.4-9.

大沼匡之・小島忠三郎 (1950): 積雪自記計の試作, 雪水, 12, pp.20-23.

岡本 隆・黒川 潮・松浦純生・浅野志穂・松山康治 (2004): 山地の積雪深分布計測における航空レーザスキャナの適用性に 関する検討, 水文・水資源学会誌, 17, pp.529-535.

Schmidt, R. A. and Pomeroy, J. W. 1990. Bending of a conifer branch at subfreezing temperatures: implications for snow interception. Canadian Journal of Forest Research 20 : 12501253. DOI:10.1139/×90-165.

志水俊夫 (1990): 森林伐採が融雪流出に及ぼす影響, 雪水, 52 , pp.29-34.

志水俊夫・吉野昭一(1996): 等高線に沿った帯状伐採が融雪流 出に及ぼす影響, 雪水, 58, pp.3-10.

杉山利治 (1970) : 空中写真による山地積雪分布の測定, 雪水, 32, pp.55-62.

高橋喜平 (1968) 最深積雪指示計について, 雪水, 30, pp.111-114. 高崎正義・瀬戸玲子・五百沢智也 (1964) : 空中写真による積雪深 調査, 雪水, 26, pp.13-18.

Tsuboyama, Y., Shimizu, A., Kubota, T., Abe, T., Kabeya, N., Nobuhiro, T. 2008. Measurement of snow depth distribution in a mountainous watershed using an airborne laser scanner. Journal of Forest Planning 13:267-273.

吉田竹松 (1962)：樹木の周りの積雪の一性質について(標識板と 測深棒による積雪深の比較), 雪氷, 24, pp.47-49.

Ziegler, A.D., Negishi, J.N., Sidle, R.C., Noguchi, S., and Abdul Rahim, N. 2006. Impacts of logging disturbance on hillslope saturated hydraulic conductivity in a tropical forest in Peninsular Malaysia. Catena 67:89-104. DOI: 10.1016/j.catena.2006.02.008.

(受付：2009年11月17日，受理：2010年4月5日） 


\title{
Snow Depth Compared Between Thinned and Unthinned Cryptomeria Japonica Forest Stands
}

\author{
Shoji NOGUCHI ${ }^{1^{*}} \quad$ Tomonori KANEKO ${ }^{2)} \quad$ Satoru WADA $^{2)} \quad$ Tomomi ISHIKAWA $^{2)}$ \\ 1) Forestry and Forest Products Research Institute Tohoku Research Center \\ (92-25 Nabeyashiki, Shimo-Kuriyagawa, Morioka 020-0123, Japan) \\ 2) Institute of Forestry, Akita Prefecture Agriculture, Forestry and Fisheries Research Center \\ (47-2 Idoshiridai, Kawabe-Toshima, Akita 019-2611, Japan) \\ *Corresponding Author \\ Tohoku Research Center, Forestry and Forest Products Research Institute \\ (92-25 Nabeyashiki, Simo-Kuriyagawa, Morioka, Iwate, 020-0123, Japan) \\ (Phone: +81-19-641-2150, FAX: +81-19-641-6747, E-mail: noguchi@affrc.go.jp)
}

We compared snow depths in a Cryptomeria japonica forest of the Nagasaka experiment with a thinned slope, skid trail, unthinned slope, and meteorological station in Akita prefecture during the winter season of 2008/9. Snow depth was measured with a calibrated steel rod and estimated with temperature sensors installed at $0,25,50$ and $75 \mathrm{~cm}$ height. The snow depth during the deposition period was in order: meteorological station $>$ skid trail $>$ thinned slope $>$ unthinned slope. Snow depth declined quickest in order: meteorological station $>$ thinned slope and skid trail > unthinned slope during the snowmelt period. It was suggested that snow depth depended on the canopy openness, which affected the interception of snowfall and radiation balance. We also observed a remarkable decline in snow depth caused by subsurface flow during snowmelt runoff in the skid trail. A snow depth recorder of the thermometer type was effective to measure snow depth in the forest and to identify snowmelt runoff.

Key words : snow depth, snowmelt water, thinning, thermometer, skid trail, canopy openness 